\title{
EFEKTIVITAS PENGELOLAAN MASJID
}

( Studi Kasus Masjid Jami Al Muttaqin Kelurahan Wattang Kecamatan Polewali Kabupaten Polewali Mandar)

\section{Mirwan}

Prodi Hukum Ekonomi Syariah, Fakultas Agama Islam, Universitas Al Asyariah Mandar mirwan@yahoo.co.id

\begin{abstract}
Abstrak
Penelitian ini membahas tentang efektivitas Pengelolaan Manajemen Masjid studi kasus Masjid Jami Al Muttaqin Kelurahan Wattang Kecamatan Polewali Kabupate Polewali Mandar. Dengan pokok permasalahan bagaimana cara pengelolan Masjid Jami Al Muttaqin Kelurahan Wattang Kecamatan Polewali Kabupaten Polewali Mandar, dan peluang dan tantangan yang dihadapi dalam pengelolan masjid jami Al Muttaaqin Keluraha Wattang Kecamatan Polewali tersebut. Dalam pengumpulan data, digunakan motode penelitian lapangan seperti observasi, wawancara atau interviw, untuk mengetahui bagaimana pengelolaan Masjid Jami Al Muttaqin Kelurahan Wattang tersebut dan peluang dan tantangan Masjid Jami Al Muttaqin Di Kelurahan Wattang Kecamatan Polewali Kabupaten Polewali Mandar. Metode analisis yang digunakan adalah deskriftif kualitataif yang bertujuan untuk memberikan deskripsi mengenai subjek penelitian yang berdasarkan dari sumber data yang di perole dari subjek yang diteliti. Hasil penelitian yang dilakukan oleh peneliti menunjukkan bahwa efektivitas pengelolaan manjemen masjid jami Al Muttaqin Keluranhan Wattang Kecamatan Polewali Kabupaten Polewali Mandar. Memberikan dampak positif dan yang semestinya terjadi pada setiap masjid-masjid.
\end{abstract}

Kata Kunci: Efektivitas, Pengelolaan Masjid

\section{PENDAHULUAN}

Masjid adalah rumah tempat ibadah umat Muslim. Masjid artinya tempat sujud, mesjid berukuran disebut musholla, langgar atau surau. Selain tempat ibadah masjid juga merupakan pusat kehidupan komunitas muslim. Kegiatan - kegiatan perayaan hari besar, diskusi, kajian agama, ceramah dan belajar Al Qur'an sering dilaksanakan di Masjid. Bahkan dalam sejarah Islam, masjid turut memegang peranan dalam aktivitas sosial kemasyarakatan hingga kemiliteran. ${ }^{1}$

Dalam perspektif Islam, setiap tempat yang dijadikan tempat shalat bisa disebut masjid. Rasulullah Saw menyatakan, bumi adalah masjid bagi umat Islam. Artinya, kaum Muslim tidak selalu harus di masjid jika hendak shalat, tapi bisa di mana pun selama tempatnya suci dan kondusif untuk shalat. "Aku diberi lima hal yang tidak diberikan kepada seorang pun sebelumku: aku dimenangkan dengan perasaan takut yang menimpa musuhku dengan jarak sebulan perjalanan, bumi dijadikan bagiku sebagai mesjid dan suci, siapa pun dari umatku yang menjumpai waktu shalat, maka shalatlah...." (HR Bukhari)

Masjid adalah bangunan pertama yang didirikan Rasulullah Saw saat tiba di Yatsrib (Madinah) dalam peristiwa hijrah, yaitu Masjid Quba, yang hingga kini masih berdiri kokoh di Kota Madinah, Arab Saudi. Setelah Masjid Quba, Nabi Muhammad Saw dan para sahabat

\footnotetext{
${ }^{1}$ https://id.wikipedia.org/wiki/Masjid
} 
mendirikan Masjid Nabawi pada 18 Rabiul Awal tahun pertama Hijriah. Masjid Nabawi dikatakan "menyatu" dengan kediaman beliau Saw. Pada masa itu, bentuk Masjid Nabawi sangat sederhana, yakni berdinding batu bata. Bagian sebelah utara diberi atap dan pada awalnya bagian utara adalah kiblat, yaitu Bayt Al-Maqdis, dan masjid adalah bangunan yang terindah dalam suatu negri, imam Muslim rahimahullah meriwayatkan di dalam Shahihnya :

Dari Abu Hurairah -radhiyallahu'anhu- Rasulullah shallallahu 'alaihi wa sallam bersabda, "Bagian negeri yang paling Allah cintai adalah masjid-masjidnya, dan bagian negeri yang paling Allah benci adalah pasar-pasarnya." (HR. Muslim)

Masjid yang berdiri kokoh dan memeliki jamaah yang solid, serta memiliki tahfiq quran dan juga tempat pengajian anak TPA menjadi idaman dalam pengurusan suatu masjid dimanapun berada, jika melihat masjid-masjid yang ada khususnya kabupaten polewali mandar, adalah sesuatu yang langka sehingga dengan ini juga penulis berencana meneliti masjid masjid tersebut.

Pengelolaan masjid dengan baik sangat mempengaruhi dalam meningkatkan sumberdaya manusianya, menjadi ukuran secara umum jika sumberdaya manusia yang mengelola mesjid adalah orang terlatih maka tentu mesjid akan lebih sangat bermanfaat pada lingkungan sekitarnya. Masjid yang berdiri di Kelurahan Wattang Kecamatang polewali Kabupaten Polewali Mandar tepatnya Masjid jami Al Muttaqin adalah salahsatu masjid yang memiliki tahfik TPA ( tempat pengajian anak ), remaja masjid, dengan ini penulis akan mengambail penelitian pada masjid tersebut, dengan meneliti efektivitas pengelolaan masjid, dengan mengambil judul efektivitas pengelolaan masji studi kasus masjid jami al muttaqim kelurahan polewali kabupaten Polewali Mandar.

Pengelolaan keuaagan pada masjid agar lebih terarah dalam pengalokasianya tentu ini tidak muda, apa lagi menyankut keugang masjid, semampu mungkin dapat membuat keuangan tersebut lebih maksimal. Dengan melihat kondisi masjid AL muttaqin dengan adanya santri hafis quran, teka $\mathrm{Al}$ muttaqin dan panti asuhan $\mathrm{Al}$ muttaqin, seperti yang telah di sebutkan diatas untuk meneliti di masjid tersebut, peneliti tertarik degan penelitian ini, dengan berharapa menjadikan para jamaah sadar akan pentinnya pengelolan masijid dengan baik, mengabil pelajarang pada masjid untuk di jadikan acuan, serta menjadi pelajarang yang sangat penting dalam pengembangan masjid, olehnya itu penelitian yang akan dilakukan, juga kami harap dapat menjadi salah satu objek kajian selanjutnya, pada tahuntahun berikutnya dalam pengembangan masjid-masjid khususnya pada masjid Al muttaqim.

Berdasarkan uraian latar belakang di atas, maka perlu diadakan sebuah penelitian untuk memperoleh informasi yang jelas disertai bukti ilmiah. Maka sanagat tepatlah penulis mengambil obyek kajian mengenai Efektivitas Pengelolaan Masjid studi kasus masjid al muttaqim kecematan polewali kabupaten polewali mandar sehingga dapat mempereoleh data yang lebih akurat, Efektivitas Pengelolaan Masjid studi kasus Masjid Al Muttaqim Kecematan Polewali Kabupaten Polewali Mandar mejadi keputusan penulis dalam penelitian masjid.

Berdasarkan latar belakang di atas ,maka permasalahan dalam penelitian ini adalah Bagaimana cara pengelolaan keuagan Masjid AL Muttaqin Kelurahan Watang Kecamatan Polewali Kabupaten Polewali Mandar? dan apa saja peluang dan tantangan yang di hadapi dalam pengembangan Masjid AL Muttaqin Kelurana Watang Kecamatan Polewali Kabupaten Polewali Mandar?.

Berdasarkan rumusan masalah, maka tujuan penelitian adalah ntuk mengetahaui cara pegelolaan dana masjid Al Muttaqim dan untuk mengetahui penerapan atau cara yang dilakukan dalam pengelolaan dana yang ada. 
Dalam penelitian ini, hasil yang akan dicapai diharapkan akan membawa manfaat yang banyak, antara lain adalah sebagai berikut:

1. Secara umum

a. Menjadi teori dalam mewujudkan masjid-masjid yang ideal

b. Memudahkan lanka untuk mambangun kebersamaan dalam mengurus jamaah.

c. Mengembalikan masjid dalam membentuk karakter ummat

2. Secara khusus

a. Mengetahui punsi-punsi masjid

b. Mengambil pelajaran yang dalam tentan pengurusan masjid karna masjid adalah cetakan para intelektual muslim dan muslimat

c. Sebagai langka dalam mengetahui sejauh mana masjid Al Muttaqim dalam pembinaan jamaahnya

\section{TINJAUAN PUSTAKA}

\section{A. Manajemen}

Manajemen lahir sebagai tuntutan perlunya pengaturan hubungan antara individu dalam suatu masyarakat, adanya kebutuhan negara untuk menjalankan pungsi dan tanggun jawabnya, terhadap masyarakatnya dalam bentuk mengatur dan memberikan pelayanan sosial dan ekonomi masyarakat ${ }^{2}$

1. Pengertian Manajemen

Manajemen berasal dari kata to manage yang artinya mengatur. Pengaturan dilakukan melalui proses dan diatur berdasarkan urutan dari fungsi-fungsi manajemen itu. Jadi manajemen itu merupakan suatu proses untuk mewujudkan tujuan yang diinginkan.

Dari segi etimologi, manajemen berasal dari bahasa Inggris berupa kata kerja " to manage" yang sinonimnya antara lain to hand (mengurus), to control (memeriksa), to guide (memimpin), jadi apabila hanya dilihat dari asal katanya manajemen berarti pengurusan, pengendalian, memimpin atau membimbing ${ }^{3}$.

Adapun pengertian manajemen mempunyai tiga pandangan, yaitu manajemen sebagai proses, manajemen sebagai kolektifitas, dan manajemen sebagai seni dan ilmu'.

a. Manajemen sebagai suatu proses, pendapat yang dikemukakan oleh para ahli berbeda-beda, diantaranya : George R. Terry, dikutip oleh manullang dalam buku Dasar-Dasar pengorganisasian, penggerakan dan pengawasan yang dilakukan untuk mencapai tujuan yang telah ditentukan dengan menggunakan tenaga manusia dan sumber lainnya.

b. Manajemen sebagai suatu kolektifitas, adalah kolektifitas orang-orang yang melekukan aktifitas manajemen, dengan kata lain segenap orang-orang yang melakukan aktifitas manajemen dalam suatau lembaga tertentu. Dalam arti singular (tunggal) disebut manajemen, menurut Prof Drs. Zaini Muchtarom, " Manajemen adalah aktifitas untuk mengatur kegunaan sumber daya bagi terciptanya tujuan organisasi secara efektif “

2.Ma'ruf Abdullah, Manajemen barbasis sayriah halaman halama satlolaan keuangan masjidu (1) aswaja presindo yogyakarta 2013

${ }^{3}$ Anton Athoillah Dasar-Dasar Manajemen 
c. Manajemen sebagai suatu seni dan ilmu, Chester I Barnard dalam bukunya The Function of the Executive, yang dikutup oleh Manullang mengakui bahwa manajemen itu adalah suatu "seni"dan sebagai ilmu M. Manullang, Dasar-Dasar Manajemen, (Jakarta : Ghalia Indonesia, 1996). Cet. Ke A.M. Kadarman dan Yusuf Udaya, Pengantar ILmu Manajemen, (Jakarta : PT. Gramedia Pustaka Utama, 1997), H. Zaini Muchtarom, Dasar Dasar Manajemen Dakwah, (Yogyakarta : Al-Amin dan IKFA, 1996) ilmu"

Demikian pula Henry fayol, Alfian Brown, Hororid Koontz, Cyryl O'Donnel, dan George R. Terry yang dikutip juga oleh manullang dalam bukunya Dasar-Dasar Manajemen berpendapat bahwa "Manajemen itu adalah suatu seni seksligus suatu ilmu". Manajemen sebagai seni berfungsi untuk mencapai tujuan yang nyata mendatangkan hasil yang manfaat, sedangakan manajemen sebagai suatu ilmu berfungsi menerangkan fenomena-fenomena (gejala-gejala), kejadian-kejadian, keadaan-keadaan, jadi sifatnya memberikan penjelasan-penjelasan.Tak dapat disangkal lagi bahwa manajemen adalah suatu hal penting yang menyentuh, mempengaruhi dan bahkan merasuki hampir seluruh aspek kehidupan manusia layaknya darah dalam raga. Juga lebih dimengerti bahwa dengan manajemen, manusia mampu mengenali kemampuannya berikut kelebihan dan kekurangannya sendiri. Manajemen menunjukan cara-cara yang lebih efektif dan efisien dalam pelaksanaan suatu pekerjaan.Dari beberapa definisi manajemen yang dipaparkan di atas, bahwasahnya manajemen telah memungkinkan untuk mengurangi hambatan-hambatan dalam pencapaian suatu tujuan dandapat ditarik kesimpulan bahwa manajemen adalah suatu proses pengaturan kerja yang terdiri dari kegiatan-kegiatan yang telah ditentukan baik dari perencanaan, pengorganisasian, penggerakan dan tindakan pengawasan, yang dilakukan

2. Pentunjuk Syariah Tentang Manajemen

a. Manajemen bagian dari syariah

Dalam pandangan Islam segala sesuatu harus dilakukan secara rapi, benar, tertib, teratur dan tuntas tidak boleh dilakukan secara asal-asalan. Apa yang diatur dalam Islam ini telah menjadi indikator pekerjaan manajemen rapi, benar, tertib, teratur dan sistematis. Apa yang telah diatur dalam sistem Islam itu adalah berdasarkan syariat Islam. Dengan demikian dapat disimpulkan :

(1) Manajemen merupakan bagian dari sayriat Islam

(2) Manajemen Islam identik atau sama dengan manajemen syariah palintidak untuk pemahaman kita di Indonesia. ${ }^{4}$

b. Organisasi Memerlukan Manjemen

Apapun bentuk organisasi itu iya memerlukan manajemen. Suatu kelambagaan seperti institusi pemerintah atau perusahaan bahkan rumah tangga sekalipun akan berjalan dengan baik jika dikelolah dengan baik ( teratur, rapi, benar, tertib dan siste mantis). Sebaliknya apa bila suatu organisasi/lembaga/perusahaan yang tidak diorganisir dengan baik/tidak dimanaj dengan baik akan dapat dikalahkan oleh kebatilan yang di organisir

\footnotetext{
${ }^{4}$ H.M.ma'ruf Abdullah Manajemen berbasisi syariah halaman tiga belas (13) aswaja presindo, yogyakarta 2013
} 
dengan baik ( ungkapan Ali bin Abi thalib r,a ). Dominasi kemunkaran sering terjadi bukan karena kuatnya kemunkaran itu akan tetapi tidak rapinnya kekuatan yang hak. ${ }^{5}$

Banyak contoh yang bisa kita lihat dengan kebenaran ungkapan Ali bin Abi Thalib r.a ini. Misalnya tentang eksploitasi pengelolan sumberdaya alam ( pertambangan). Kita punya Undang-Undang tetang pengelolan sumberdaya Alam, namun karena manusiamanusia yang berwenang memebri izin pengelolaannya dan yang berkewajiban mengawasi pelaksanaanya lebih menguntukan sehingga ketentuan dalam undang-undang tersebut tidak dijalankan sebagaiman mestiny.

Persolan dan sitem manajemen yang diterapkan Rasulullah bersipat tidak mengikat bagi para pemimpin dan ummat setelahnya. Persoalan hidup terus berkemban dan berubah searah dengan peraturan waktu dan perbedaan tempat. Yang dituntut oleh sayariat adalah para pemimpin dan ummatnya harus berpegan teguh pada asas manfaat dan masalah, serta tidak menyianyiakan ketentuan nash syar;i. Namun mereka tid $\mathrm{k}$ terikat untuk mengikuti sistem manjemen Rasul.

Standar asas manfaat dan masalh tidak bersifat rigit. Ia bisa berubah dari waktu kewaktu, dan dari satu tempat ketempat yang lainnya. Untuk itu manjemen dalam Islam berstandar pada hasil ijtihad pemimpin dan ummatnya dengan catatan ia tidak boleh bertentangan dengan konsep dasar dan perensip hukum utamanya yang bersumber dari Alquran dan Al sunnah, serta tidak bertolak belakan dengan rincian hukum syara yang telah dimaklumi. Ummat muslim masih memiliki ruang untuk melakukan inovasi atas persoalan detail yang belum terdapat ketentuan syar'inya.

\section{Beberapa unsur manajemen, yaitu :}

\section{a. Man (manusia)}

Manusia adalah unsur pendukung yang paling penting dalam manajemen, karena pada dasarnya manajemen dilakukan oleh manusia, untuk dan kepada manusia. Dan tanpa kegiatan yang dilakukan oleh manusia tujuan pasti tidak akan tercapai, namun manusia itu sendiri harus didukung dengan unsur lain agar tujuan yang ingin manusia capai dapat terpenuhi. ${ }^{6}$

\section{b.Money (uang)}

Uang adalah sarana atau unsur kedua setelah manusia, karena uang dipakai untuk pelaksanaan kerja dan pelaksanaan semua fungsi-fungsi pimpinan demi tercapainya tujuan dengan setepat-tepatnya. Uang juga dipakai untuk perangasang, maksudnya untuk member imbalan pada tenaga manusia tadi dan sebagai sarana manajemen agar tujuan manusia tercapai.

\section{c. Material (materi)}

Di Indonesia kata material (materi) sering disebut dengan kata perbekalan. Dalam organisasi dan manajemen ini material diartikan sebagai sumber yang diperlukan bagi pelaksanaan fungsi-fungsi pimpinan, dan juga bagi pencapaian tujuan organisasi, supaya tujuan organisasi tersebut tidak terputus di tengah jalan.

${ }^{5}$ H.M.ma'ruf Abdullah Manajemen berbasisi syariah halaman lima belas belas (15) aswaja presindo, yogyakarta 2013

${ }^{6}$ H.M.ma'ruf Abdullah Manajemen berbasisi syariah halaman tiga belas (13) aswaja presindo, yogyakarta 2013 


\section{B. Manajemen Keuangan}

Manajemen keuangan ( keuangan perusahaan ) adalah pengelolaan aliran dana perusahaan untuk mencapai tujuan perusahaan yang telah di gariskan ${ }^{7}$. Pengertian manajemen keuangan menurut Liefman : Manajemen Keuangan merupakan usaha untuk menyediakan uang dan menggunakan uang untuk mendapat atau memperoleh aktiva.Pengertian manajemen keuangan menurut Erlina, SE. Manajemen keuangan merupakan manajemen terhadap fungsifungsi keuangan. Fungsi-fungsi keuangan tersebut meliputi bagaimana memperoleh dana (raising of fund) dan bagaimana menggunakan dana tersebut (allocation of fund). Pengertian manajemen keuangan menurut Depdiknas : Manajemen keuangan merupakan tindakan pengurusan/ketatausahaan keuangan yang meliputi pencatatan, perencanaan, pelaksanaan, pertanggungjawaban dan pelaporan. Pengertian manajemen keuangan menurut Prawironegoro : Aktivitas pemilik dan manajemen perusahaan untuk memperoleh modal yang semurah-murahnya dan menggunakan seefektif, seefisien, dan seproduktif mungkin untuk menghasilkan laba. Pengertian manajemen keuangan menurut Suad Husnan : Manajemen Keuangan ialah manajemen terhadap fungsi-fungsi keuangan.

1. Garis Besar Dari Fungsi Manajemen Keungan

a. Mencari/mendapatkan/mengumpulakan dana

b. Mengunakan dana untuk imvestasi, pembiyaan investasi, setra untuk pembelanjaan perusahaan secara efesien.

Tujuannya adalah untuk memaksimumkan nilai perusahaan atau memaksimalkan kemakmuran pemegan saham dan memaksimumkan kesejahteraan karyawannya. Sehubungan dengan hal tersebut, maka aktivitas manjemen keuangan terdiri dari tiga bidang yang saling terkait, sebagai berikut.

a. Sehubungan dengan keuangan perusahaan, kegiatannya meliputi: memutuskan besarnya kebutuhan modal kerja, umur piutang dari pelanggannya, besarnya uang kas, menentukan besarnya laba/dividen yang harus dibayarkan memebuat keputusan investasi untuk perluasan usahan termasuk sumberdananya. Untuk hal tersebuat manajemen keungan harus bekerja sama dengan bidang lain agar perusahaan beroperasi seefisien munkin.

b. Dalam hubungannya dengan kebutuhan tambahan modal atau munkin kelbihan dana untuk diimvestasikan dalam sekuritas dapat berinteraksi dengan pasar uang dan pasar melalui lembaga keungan.

c. Manejer harus berinteraksi dengan eksekutif lainnya dalam memperkirakan masa depan perusahaan dan menetapkan rencana bersama untuk menentukan posisi masa depan perusahan ${ }^{8}$

\section{Tujuan Manajemen Keuangan}

Tujuan Manajemen Keuangan adalah untuk memaksimalkan nilai perusahaan. Dengan demikian apabila suatu saat perusahaan dijual, maka harganya dapat ditetapkan setinggi mungkin. Seorang manajer juga harus mampu menekan arus peredaran uang agar

\footnotetext{
${ }^{7}$ Hananto soeweto Manajemen keuangan dan akutansi perusahaan pelayaran. Halaman satu -Ed. 1-1 jakarta: PT. Raja Grafindo persada 2007

${ }^{8}$ Hananto soeweto Manajemen keuangan dan akutansi perusahaan pelayaran. Halaman satudua -Ed. 1-1 jakarta: PT. Raja Grafindo persada 2007
} 
terhindar dari tindakan yang tidak diinginkan. Namun, Manajemen keuangan yang efisien memenuhi adanya tujuan yang digunakan sebagai standar dalam memberi penilaian keefisienan (Sartono: 2000, 3) yaitu, tujuan normatif manajemen keuangan adalah memaksimalkan kemakmuran pemegang saham yaitu memaksimalkan nilai perusahaan, seperti :

a. Tujuan memaksimumkan kemakmuran pemegang saham dapat ditempuh dengan memaksimumkan nilai perusahaan.

b. Secara konseptual jelas sebagai pedoman dalam pengambilan keputusan yang mempertimbangkan faktor risiko.

c. Manajemen harus mempertimbangkan kepentingan pemilik, kreditor dan pihak lain yang berkaitan dengan perusahaan.

d. Memaksimalkan kemakmuran pemegang saham lebih menekankan pada aliran kas dari pada laba bersih dalam pengertian akuntansi.

e. Tidak mengabaikan social objectives dan kewajiban sosial, seperti lingkungan eksternal, keselamatan kerja, dan keamanan produk.

\section{Tujuh Prinsip Manajemen Keuangan}

Manajemen keuangan bukan hanya berkutat pada seputar pencatatan akutansi. Dia merupakan bagian penting dari manajemen program dan tidak boleh dipandang sebagai suatu aktivitas tersendiri yang menjadi bagian dari pekerjaan orang keuangan. Ada 7 Prinsip dari manajemen yang harus diperhatikan.

a. Konsistensi (consistency)

Sistem dan kebijakan keuangan dari organisasi harus konsisten dari waktu ke waktu. Ini tidak berarti bahwa sistem keuangan tidak boleh disesuaikan apabila terjadi perubahan di organisasi. Pendekatan yang tidak konsisten tehadap manajemen keuangan merupakan suatu tanda bahwa manipulasi di pengelolaan keuangan.

b. Akuntabilitas(accountability)

Akuntabilitas adalah kewajiban ,moral atau hukum, yang melekat pada individu, kelompok atau organisasi. Organisasi harus dapat menjelaskan bagaimana dia menggunakan sumber dayanya dan apa yang telah dia capai sebagai pertanggumg jawaban kepada pemangku kepentingan dan penerima manfaat.

c. Transparansi (transparancy)

Organisasi harus terbuka berkenaan dengan pekerjaannya,menyediakan informasi berkaitan dengan rencana dan aktivitasnya kepada para pemangku kepentingan. Termasuk didalamnya, menyiapkan laporan keuangan yang akurat, lengkap, dan tepat waktu serta dapat dengan mudah dpat diakses oleh pemangku kepentingan dan penerima manfaat. Apabila organisasi tidak transparan, hal ini mengindikasikan ada sesuatu hal yang disembunyikan.

d. Kelangsungan hidup (integrity)

Agar keuangan terjaga pengeluaran organisasi ditingkat stratejik maupun operational harus sejalan /disesuaikan dengan dana yang diterima. Kelangsungan hidup atau (viability) merupakan suatu ukuran tingkat keamanan dan keberlanjutan keuangan organisasi.

e. Integritas (integrty)

Dalam melaksanankan kegiatan operationalnya, individu yang terlibat harus mempunyai integritas yang baik. selain itu, laporan dan catatan keuangan harus tetap dijaga integritasnya melalui kelengkapan dan keakuratan pencatatan keuangan.

f. Pengelolaan (stewardship) 
Organisasi harus dapat mengelola dengan baik dana yang telah diperoleh dan menjamin bahwa dana tersebut digunakan untuk mencapai tujuan yang telah ditetapkan.

\section{g. Standar akutansi (accounting standarts)}

Sistem akuatansi dan keuangan yang diguanakn organisasi harus sesuai dengan prinsip dan standart akutansi yang berlaku umum.

\section{Contoh Kegiatan Manajemen Keuangan}

Manajemen keuangan perlu di terapkan didalam semua organisasi, terutama sebuah organisasi besar yang berbentuk perusahaan seperti Rumah Sakit.

Rumah sakit, adalah contoh perusaan dalam dunia kesehatan, dan semua kegiatannya diatur dengan baik dengan manajemen, salah satunya manajemen keuangan yang di terapkan di rumah sakit, seperti akuntansi rumah sakit.

\section{Masjid}

1. Pengertian Masjid

Pengertian masjid secara istilah adalah "tempat sujud yaitu tempat umat Islam mengerjakan shalat, zikir kepada Allah SWT, dan untuk hal- hal yang berhubungan dakwah Islamiyah". Masjid secara umum seringkali diidentikan dengan tempat shalat bagi mereka yang mengaku Islam sebagai agamanya. Sejak zaman Nabi masjid selain difungsikan sebagai tempat pelaksanaan ibadah, juga sebagai pusat kebudayaan, pusat ilmu pengetahuan ${ }^{9}$, pusat informasi, pusat pengembangan ekonomi kerakyatan, pusat pengaturan strtegi perang, serta pusat pembinaan dan pengembangan sumber daya umat secara keseluruhan. Pengertian ini memberi gambaran, bahwa masjid di samping tempat sujud, juga mempunyai peran ganda dalam pengembangan dakwah Islam. M. HR. Songge menyatakan masjid secara etimologis, bermakna sebagai tempat para hamba yang beriman bersujud melakukan ibadah mahdhah berupa shalat wajib dan berbagai shalat sunnah lainnya kepada Allah SWT, dimana para hamba melakukan segala aktifitas baik yang bersifat vertikal maupun horizontal dalam kerangka beribadah kepada Allah SWT. Dari pengertian tentang masjid di atas, penulis dapat menyimpulkan bahwa pengertian masjid adalah suatu tempat dimana M. Abdul Mujid, Kamus Istilah Fiqih (Jakarta: PT. Pustaka Firdaus, 1994), h. 201.M. Hr. Songge, Pesan Risalah Masyarakat Madani, (Jkarta: PT. Media Citra, 2001) seseorang dapat melakukan sujud, merendahkan diri, dan menyembah tuhan. Serta tempat untuk memecahkan permasalahan yang berhubungan dengan persoalan manusia atau dengan kata lain tempat seseorang untuk melakukan aktivitas baik yang bersifat vertikal maupun yang bersifat horizontal.

2. Tujuan Masjid.

Dengan semangat tinggi masjid yang kita bangun secara bergotongroyong, saling membantu, berkorban menyalurkan harta shadaqah, infak dan wakaf demi berdirinya masjid bangunan suci Allah SWT dan tanpa memendang kaya, miskin atau golongan, masjid-masjid dapat berdiri dengan megahnya, layaknya kawasan taman-taman surga nan indah dan damai. Hendaknya masjid jangan sampai sepi dalam syi'ar atau kegiatannya olehnya itu masjid adalah tempat ibadah, pembelajran, tempat bermusyawarah asrama dan lain-lain.

Umat Islam berusaha untuk bangkit. Kebangkitan ini memerlukan peran Masjid sebagai basis perjuangan. Kebangkitan berawal dari Masjid menuju masyarakat secara luas. 
Karena itu upaya aktualisasi fungsi dan peran Masjid pada abad lima belas Hijriyah adalah sangat mendesak (urgent) dilakukan umat Islam.. ${ }^{10}$

\section{Sejarah Masjid}

Masjid yang berdiri megah dan kokoh, yang didirikan sebelum kemerdekaan indonesia sekitar tahun 1912 M yang setiap kali kita melihatnya ketika berada di alung alung pantai bahari polewali tepatnya pada kelurahan wattang mesjid tersebut dapat kita lihat.

Awalmula didirikan masjid wattang, yang berawal dari pembeicaraan seorang guru dari desa pambusuang yang bernama KH. Saifuddin yang melakukan perjalanan karna mendapat tugas sebagai kadi di kelurahan wattang tempat masjid didirikan, dan bertemu dengan A. Tanrato daeng mangemba seorang hartawan yang budiman memiliki cita cita mulia tersebut, yang kemudian melahirkan suatu pembicaraan untuk membangunsuatu masjid pada wilayah tersebut. Pertemua yang malahirkan sutau masjid yang bernama $\mathrm{Al}$ muttakim kecamatang polewali kelurahan wattang kabupateng polewali yang sampai saat ini masih dapat kita lihat masjid tersebut.

Pengembangan masjid yang seringkali dilakukan sejak masjid didirikan samapai sekarang ini tiada lain adalah hasil musyawarah masarakat sekeliling masjid yang konon dulu sejak awal masjid didirikan pemilik masjid yang mula mula mendirikan masjid tersebut tidak menerima swadayaa masyarakat sedikupunn dalam pengembangan masjid dan pada ahirnya masyrakat ikut membantu pembangunan masjid tesebut, dan sampai panda penelitian kami tertarik untuk menelitinya bukan hanya pada bangunan pisik yang membuat tertarik tetapi bangun non pisikpun juga menjadi keter tariakan sebutan untuk lebih memahami giat-giat apa saja yang dilakukan dalam pengembangan masjid yang berada pada kelurahan wattang kecamatang polewali kabupaten polewali, sehingga juga dapat menjadi pedoman masjid masjid lainnya $^{11}$

\section{METODE PENELITIAN}

Dalam melakukan penelitian ini, penulis mengambil lokasi sesuai dengan judul peneliti "Efektivitas Pengelolaan Manajemen Masjid studi kasus Masjid Jami Al Muttaqin Kelurahan Wattang Kecamatan Polewali Kabupate Polewali Mandar.

Jenis dari penelitian ini adalah penelitian deskriptif (description research). Tujuan penelitian deskriptif adalah untuk menggambarkan/ memecahkan masalah secara sistematis, faktual, dan akurat mengenai fakta-fakta dan sifat-sifat populasi atau daerah tertentu. ${ }^{12}$

Jenis penelitian adalah penelitian deskriptif merupakan penelitian paling sederhana, dibandingkan dengan penelitian-penelitian yang lain karena dalam penelitian ini peneliti tidak melakukan apa-apa terhadap objek atau wilayah yang diteliti. Ini artinya bahwa dalam penelitian, peneliti tidak mengubah, menambah, atau mengadakan manipulasi terhadap objek atau wilayah penelitian. ${ }^{13}$ Dan jenis dari penelitian deskriptif yang peneliti gunakan adalah penelitian korelasi sebab akibat dimana peneliti bermaksud untuk mengetahui bagaimana

${ }^{10}$ http://www.masjidrayavip.org 25 oktober 2017

${ }^{11}$ Wawancara lansung dengan pengurus masjid al muttaqin kelurahan wattang (imam masjid)

12 Usman Rianse dan Abdi, Metodologi Penelitian Sosoal dan Ekonomi Teori dan Aplikasi, (Bandung: Alfabeta, 2012), hal 30

13 Sugiyono, Metode Penelitian Kuantitatif, Kualitatif dan R\&D, (Bandun: Alfabeta, 2011) hal 3. 
pengembangan manajemen masjid sehingga masjid semakin berkambang cara apa yang dilakukan para panitia masjid Al Muttaqim.

Berikut adalah metode pengumpulan data yang digunakan dalam penelitian ini yaitu:

1. Metode Angket adalah alat penelitian berupa daftar pertanyaan untuk memperoleh keterangan dari sejumlah responden. ${ }^{14}$ Angket ini diberikan kepada responden yaitu masyarakat jamaah Masjid AL Muttaqin Kelurahan Watang Kecamatan Polewali Kabupaten Polewali Mandar.

2. Metode wawancara adalah suatu dialog yang dilakukan oleh pewawancara untuk memperoleh informasi dari terwawancara. ${ }^{15}$ Metode ini digunakan untuk mengumpulkan data-data yang diperoleh yang dianggap kurang dalam mencari data melalui metode angket.

Populasi adalah seluruh Populasi yang akan menjadi sampel penelitian adalah seluruh pengurus Masjid Al Muttaqim Kelurahan Wattan Kecamatan Polewali Kabupaten Polewali Mandar.

Sampel adalah sebagian sumber data yang di ambil dari populasi. Idealnya prosedur penarikan sampel itu harus dilakukan sedemikian rupa sehingga setiap unit didalam populasi memperoleh kesempatan yang sama.Sampel merupakan bagian populasi yang diangap mewakili dari semua objek dari sasaran penelitian atau prosese menarik sebagian subjek ${ }^{16}$ Disamping itu, sutrisno hadi mengatakan bahwa sampel adalah "sebagian induvidu yang di teliti" ${ }^{17}$ Sampel di pergunakan untuk penelitian yang sifat dan karakternya dapat mewakili populasi sebagai subjek penelitian. Karna jumlah populasi kurang dari 100 maka penulis mengabil sampel dari seluruh pengurus Masjid Jami Al Muttaqim Kelurahan Watang Kecamatang Polewali Kabupaten Polewali Manda.

Sumber data dalam penelitian ini adalah subyek dari mana data diperoleh. ${ }^{18}$ Sumber data dalam penelitian ini dikelompokkan menjadi 2 macam, yaitu:

1. Data primer, yaitu data yang didapat dari sumber pertama dilapangan. ${ }^{19}$ Jenis data ini sering disebut dengan istilah data mentah berupa hasil Angket dengan responden masyarakat Masjid Masjid AL Muttaqin Kelurahan Watang Kecamatan Polewali Kabupaten Polewali Mandar.

2. Data sekunder merupakan data yang berasal dari sumber kedua yang dapat di peroleh melalui buku-buku, brosur dan artikel yang didapat dari website yang berkaitan dengan penelitian ini. ${ }^{20}$. Untuk memperoleh data ini peneliti mengambil sejumlah buku-buku, brosur, website, dan contoh penelitian sebelumnya yang berkaitan dengan penelitian ini.

\section{HASIL PENELITIAN}

14 Burhan Bungin, Metodologi Penelitian Sosial ..., hal 135

15 Bambang Prasetyo, Metode Penelitian Kuantitatif Teori dan Aplikasi, ( Jakarta: Grafindo,2005), hal.138

3Ibid, h.51-52

${ }_{17}^{1}$ Sutrisno Hadi, loc.cit

${ }^{18}$ Lexy J. Moleong, Metode Penelitian Kualitatif, (Bandung: Remaja Rosdakarya, 2002), 4

19 Burhan Bungin, Metodologi Penelitian Sosial: Format-format Kuantitatif dan Kualitatif, (Surabaya: Airlangga University Press, 2001), hal. 128

${ }^{20}$ Ahmad Tanzeh, Pengantar..., hal 54-55 
A. Tata cara pengelolaan keuangan masjid al muttaqin

1. Sumber pendanaan

Mesjid yang memiliki jamaah terhitung cukup banyak yang berdiri ditengah-tenga perkampungan padat penduduk, dengan mengelolah Taman Kanak - Kanak , Pengajian Dasar dan Pondok Tahfizh Alqur'an serta pengajian rutinan jamaah Masjid Jami Al Muttaqin Kelurahan Wattang.

Dari kegiatan-kegiatan pada masjid tersebuta sebagaiman yang dituliskan penulis diatas, setelah malakukan wawancara dengan beberapa pengurus masjid, yang mengatakan bahwa segala kebutuhan masjid dengan apa yang dikelola masjid, bersumber dari dana suadaya masyarakat sekitar, dan juaga beberapa proposal yang dibuat kepada pemerintah, serta dari sekitar masyarakat peloso-ploso melalui kotak amal keliling, selain itu masjid al muttaqin juga menjalankan donatur-donatur untuk menopan keungan masjid tersebut .

Uang yang masuk kemasjid atau sumbangan masjid ini berasal dari sumbangan suadaya, masyarakat sekitar, melalui donatur maupun kotak amal masjid, dan juga kotak keliling, yang dibawa sampai ke peloso-peloso luar dearah, lambi saudi Tinabung, lambi' sau di Majene. ${ }^{21}$

2. Distribusi keuangan masjid

Masyarakat jamaah masjid Al Muttaqin Kelurahan Wattang Yang Solid akan kerja sama dalam membangun jamaah, dengan di buktikan partisipasi yang cukup tinggi dalam setiap kegiatan masjid yang berlansung pada masjid tersebut, dengan sumbangan yang masuk pada masjid di gunakan pada pembangunan dan kegiatan-kegiatan pokok masjid tesebut, pada Taman Kanak - Kanak , Pengajian Dasar dan Pondok Tahfizh Alqur'an, serta pengajian rutinan jamah masjid al muttaqin. Kelurahan Wattang Kecamtan Polewali Kabupaten Polewali Mandar.

Dana yang masuk atau sumbangan yang masuk ini, kami distribusikan pada masjid untuk pembangunan, Tahfizh Alqur'an, Taman Kanak - Kanak serta pengajian rutin yang diadakan oleh jamaah masjid setiap minggunya, ${ }^{22}$

\section{B. Peluang dan Tantangan}

Dalam pembinaan ummat yang semakin moderen dan semakin berkebang yang tidak memiliki batas, adalah tantangan yang besar dan berat seperti yang kita ketahuai, bahwa dunia elektronik adalah salah satu yang sangat mempengaruhi kegiatan-kegiaatan sosila, baik dalam lingkup sekolah serta masyarakat, dan pada hususnya masyakat jamaah masjid wattang, yang juga saya katakan tidak bisa lepas dari gempuran dunia elektronik, untuk tetap menjaga kesatuan jamaah pengajian, jamaah santri, serta jamaah tempat pengajian anak pada masjid Al Muttaqin kelurahan wattang.

Hal yang sangat luar biasa sampai hari ini saya masi bisa jumpai pada masjid tersebut dengan pengajian yang ramai dan anak-anak tetap giat dalam mengikuti pengajian, atau pembelajaran pengajian pada mesjid yang peneliti teliti, pada saat melakukan wawan cara dengan salah satu pengurus masjid, dan menanyakan beberapa hal mengenai tentan reumusan masalah penelitian peneliti yang selanjutnya, yaitu apa-apa saja peluag dan tantangan yang dihadapai dalam pengembangan Masjid Al Muttaqin, secara sponta

\footnotetext{
${ }^{21}$ Wawan cara dengan bapak Imam masjid Al Muttaqin Kelurahan Wattang Kecamatan Polewali Kabupaten Polewali Mandaar

${ }^{22}$ Wawancara dengan imam Masjid Al muttaqin Kelurahan Wattang Kecamatan Polewali Kabupaten Polewali Manda.
} 
menjawab bahwa dalam pengembangan masjid dalam hal masalah keungan kami merasa tidak terlalu sulit untuk mendapatkannya karna tanpa kami menyuruhnya, untuk menyumbang atau mengeluarkan sebagian hartanya, suda ada yang mengeluarkan uangnya dan bagai mana ketika kami mengumumkannya. Kami bisa katakan jamaah disini adalah jamaah yang kompak maka disini kami tidak mimiliki kesulitan selama pengajian di masjid tetap ramai dan kegiatan lainnya tetap berjalan.

Sebagai mana penelitian dengan cara wawan cara pada tulisan diatas, sesuai apa yang saya lihat dan saya dengar bahawa dalam hal keuangan masjid tersebut tidak sedikitpun ada kendala, selama bimbingan ummat atau pengajian rutin tetap berjalan, dengan pengajian rutinan masyarakat akan pekah tetan kejadin-kejadin sosial sebagai mana apa yang kita jumpai pada mesjid tersebut dan kalau saya menyimpulkan peluang dan tantangan yang dihadapi dalam masjid tersebut adalah:

1. Peluang :

a. Dengan lokasi yang berada pada pusat keramaian yakni salah satu lokasi wisata Kabupaten Polewali, wisata pantai Bahari Polewali

b. Jamaah masjid yang kompak, dengan melihat pada kegiatan pembangunan masjid, dan ketika kami melakukan pengembangan masjid untuk mendapatkan dana pengembangan tesebut tidak sulit, dengan menyampaikan kepada jamaah bahwa kimi akan membangun ini, dengan cara melelang kepada seluruh jamaah, kendala dana dalam perencanaan pembangunan tersebut dapat diselesaikan waktu itu juga, dalam artian jamaah masjid mudah untuk diajak kerja sama.

c. Dengan mengelola Panti Asuhan, Taman Kanak - Kanak, Pengajian Dasar dan Pondok Tahfizh Alqur'an. Selain itu, sebagai bentuk perhatian dan pembinaan Ummat juga diadakan pengajian mingguan yang diadakan setiap malam Ahad, dengan Nara Sumber yang berbeda,dalam hal pengutan ummat.

"Masjid yang tetap ramai setiap malamnya, pengajian yang tetap berjalan adalah peluang dalam pengembangan masjid ${ }^{, 23}$

\section{Tantangan}

Berdasarkan pada hasil wawancara kami dengan salah satu pengurus masjid di tempat, menyatakan bahwa dalam penrusan masjid kami sedikitpun tidak terkendala dalam pengembangan masjid ini, tetapi dalam hal bagaimana agar pengajian tetap berjalan, mulai dari anak-anak samapai dewasa pengaruh teknologi dalam perkembangan jamaag khususnya pada Taman Kanak - Kanak , Pengajian Dasar dan Pondok Tahfizh Alqur'an.dan pembinaan Ummat dengan diadakan pengajian mingguan yang diadakan setiap malam Ahad adalah tantangan yang cukub berat pada setiap masjid.

"Dalam membangun masji sayarasa tidak ada tantangan yang bera yang mesti saya hadapi, yang namanya kebaikan apa lagi ini tidak ada orang yang mau menhalangi, akan tetapi kalau mempertahankan jamaah saya rasa ini tantangan yangn saya rasa juga mengkhawatirkan di kehidupan yang moderen ini, ${ }^{, 24}$

Tabel 5.2

\footnotetext{
${ }^{23}$ Wawancara dengan iamam masjid ke II Al Muttaqin Kelurahan Wattang Kecamatan Polewali Kabupaten Polewali Mandar.

${ }^{24}$ Wawan cara dengan imam Masjid ke II Al Muttaqin Kelurahan Wattang Kecamatan Polewali Kabupaten Polewali Mandar
} 
Vol. 2, No. 1, Mei 2017

p-ISSN: 2541-5212 | e-ISSN: 2541-5220

J-ALIF Jurnal Penelitian Hukum Ekonomi Syariah dan Sosial

Budaya Islam

Daftar donatur tetap masjid yang diambil pada saat melakukan penelitian. T.IV.II

\begin{tabular}{|c|c|c|c|}
\hline No & NAMA & BANYAKNYA & KET / TTD \\
\hline 1 & H. Santar & 250.000 & \\
\hline 2 & H. Hayasi & 200.000 & \\
\hline 3 & Hj. Nurmadina & 200.000 & \\
\hline 4 & Keluarga Muh. Ilham Maulana & 200.000 & \\
\hline 5 & Abrianto & 200.000 & \\
\hline 6 & Herman Rauf & 200.000 & \\
\hline 7 & Suwono & 100.000 & \\
\hline 8 & Hj. Dahniah Tasri & 100.000 & \\
\hline 9 & Hj. Rahmatiah & 100.000 & \\
\hline 10 & Hj. Dahlia Masdar F. & 100.000 & \\
\hline 11 & Hj. Rapiah Habba & 100.000 & \\
\hline 12 & Hj. Husnul Husa & 100.000 & \\
\hline 13 & H. Ahmad daen Kulle & 100.000 & \\
\hline 14 & H. Halija Biarallo & 100.000 & \\
\hline 15 & H. Lahamuddin & 50.000 & \\
\hline 16 & H. Syahril Djawas & 50.000 & \\
\hline 17 & H. Muslimin & 50.000 & \\
\hline 18 & H. Abd. Rahman & 50.000 & \\
\hline 19 & H. Alimuddin Lidda & 50.000 & \\
\hline 20 & Hj. Suhuria Aco & 50.000 & \\
\hline 21 & Dra. Masdeli & 50.000 & \\
\hline 22 & Hj. Haedar & 50.000 & \\
\hline 23 & Hj. Aisyah & 50.000 & \\
\hline 24 & H.A.Raden Madjid & 50.000 & \\
\hline 25 & Atcho Rais Raden & 50.000 & \\
\hline
\end{tabular}


Vol. 2, No. 1, Mei 2017

p-ISSN: 2541-5212 | e-ISSN: 2541-5220

J-ALIF Jurnal Penelitian Hukum Ekonomi Syariah dan Sosial

Budaya Islam

\begin{tabular}{|c|l|r|l|}
\hline 26 & Suhuria & 50.000 & \\
\hline 27 & Dra. Hj. Farida Rusin & 50.000 & \\
\hline 28 & Dra. Hj. Namriah & 50.000 & \\
\hline 29 & Hj. Supiami & 50.000 & \\
\hline 30 & Hj. Maryam Idris & 50.000 & \\
\hline 31 & Hj. Nurmia T. Lele & 50.000 & \\
\hline 32 & Hj. Sakinah & 50.000 & \\
\hline 33 & Hj. Subaedah & 50.000 & \\
\hline 34 & Hj. Rubese & 50.000 & \\
\hline 35 & Drs. H. Syamsuddin & 50.000 & \\
\hline
\end{tabular}

Sumber : Pengurus Masjid Al Muttaqim Wattang Kabupaten Polewali Mandar tahun 2017

\section{PENUTUP}

A. Kesimpulan

yaitu:

Berdasarkan pada hasil penyajian, maka penulis menarik beberapa kesimpulan,

Pelaksanaan sistem bagi hasil pada usaha ternak Kambing di Desa Lampoko menggunakan sistem revenue sharing yaitu sistem pembagian hasilnya dihitung berdasarkan jumlah pendapatan pengelola Kambing tanpa dihitung berapa biaya yang telah pengelola keluarkan dalam penggemukan Kambing tersebut. Dengan porsi nisbah dibagi dua atau 50:50. Hal ini telah terjadi kesepakatan antara kedua belah pihak, yaitu antara shahibul mal dengan mudharib. Namun sayangnya kesepakatan atau akad yang terjadi antara kedua belah pihak hanya akad lisan, bukan tulisan. Sehingga jika ada komplen dari pihak pengelola atas ketidaksesuaian dalam pembagian keuntungan, tidak bisa ditanggapi dengan tegas, karena akad yang dibuat tersebut akad lisan.

Tinjauan Ekonomi Islam mengenai usaha ternak kambing di Desa Lampoko sudah sesuai dengan prinsip syari'ah. Dalam menjalankan usaha ternak kambing tersebut pemilik modal dan pengelola modal sama-sama melakukan akad dan disepakati di awal kontrak, pemilik Kambing memberikan modal berupa uang kepada pengelola kambing untuk memelihara kambing tersebut dan keuntungan yang diperoleh akan dibagi dua atau 50\%: 50\%. Hal tersebut sudah disepakati oleh kedua belah pihak meskipun hanya melalui akad lisan. Karena jikalau memang pemilik modal mengambil uang dari hasil keuntungan tersebut untuk keperluan usaha tersebut, maka hendaklah dijelaskan kepada pengelola, dan jika ada perubahan akad dalam pembagian keuntungan maka dari awal harus dibicarakan kepada pengelola supaya tidak terjadi kesalahpahaman antara pemilik modal.

\section{B. Saran}

Hendaknya kegiatan kerjasama usaha ternak kambing ini, dalam mengembangkan usaha ini harus lebih maksimal, artinya diperhatikan dengan baik usaha ini, baik itu kontrol dari pemilik kambing serta masukan-masukan tentang kondisi kambing tersebut. 
Hendaknya pemilik kambing dalam membagi keuntungan harus jelas berapa yang diperoleh untuk mudharib. Jika memang pemilik modal mengambil uang dari keuntungan mudharib untuk hal-hal yang berkaitan dengan usaha kambing, maka ini harus dijelaskan kepada mudharib, supaya tidak terjadi kesalahpahaman antara kedua belah pihak. Karena bisnis Islami ini harus jelas dan tidak ada yang ditutupi dan tidak ada kebohongan, dan hendaknya akad yang terjalin kedua belah pihak di buat secara tulisan. Karena dalam Islam di jelaskan bahwa apabila hendak bermuamalah, melakukan transaksi hendaknya dituliskan.

\section{Daftar Pustaka}

George R. Terry Dasar-Dasar pengorganisasian Malayu S.P Hasibun Manajemen Dasar, Pengertian, dan Masalah pengertian-keuangan-menurut-para-ahli.html Pengertiankeuangan-menurut-para-ahli.html Ahmad tanzeh, pengantar ..., hal. 104.

Asrof Syafi' I, Metodologi Penelitian Pendidikan, (Surabaya: eLKAF, 2005), hlm. 134.

Abdurachman, A, 1999, Ensiklopedia Ekonomi Keuangan Lainnya, Jakarta : PT. Gramedia Pustaka(Diunggah 25 september 2016)

Burhan Bungin, Metodologi Penelitian Sosial: Format-format Kuantitatif dan Kualitatif, (Surabaya: Airlangga University Press, 2001), hal. 128

Burhan Bungin, Metodologi Penelitian Sosial ..., hal.123

Ismail, Perbankan Syariah, (Jakarta: Kencana, 2011), hal. 38

Jill Griffin, Customer Loyalty Menumbuhkan dan Mempertahankan Kesetiaan Pelanggan, (Jakarta: Erlangga, 2005) hal. 35

Lexy J. Moleong, Metode Penelitian Kualitatif, (Bandung: Remaja Rosdakarya, 2002), 4

Muhammad, Bank Syari'ah Problem dan Prospek Perkembangan di Indonesia, (Yogyakarta : Graha Ilmu, 2005)hal 78-80

Muhammad, Sistem dan Prosedur Operasional Bank Syari'ah, (Yogyakarta: UII Press, 2008), hal 2-3

Muhammad Syari’I Antonio, Bank Syariah dari Teori ke Praktik, ( Jakarta: Gema Insani, 2001), hal. 4

Wirdyaningsih, Bank dan Asuransi Islam di Indonesia, (Jakarta: Kencana Prenada Media Group, 2005),hal.1

Ongky Setio Kuncono,"Hukum Perbankan (Bagian IV) Bank Syariah", http://spocjournal.com/hukum/418-universitas-kartini-surabaya-hukum-perbankanbagian-iv-bank-syariah.html, diakses 11 Oktober 2016

Ongky Setio Kuncono,"Hukum Perbankan ... diakses 11 Oktober 2016

Ratih Hurriyati, Bauran Pemasaran dan Loyalitas Konsumen, (Bandung: Alfabeta, 2005), hal 127

Ismail, Perbankan Syariah, (Jakarta: Kencana, 2011), hal. 32-33 
Sugiyono, Statistik Untuk Penelitian,(Bandung: Alfabeta, 2006), hal. 11

Suharsimi Arikunto, Prosedur Penelitian Suatu Pendekatan Praktek, (Jakarta: Rineka Cipta, 2010), hal. 12.

Sugiyono, Metode Penelitian Kuantitatif, Kualitatif dan R\&D, (Bandun: Alfabeta, 2011) hal 3.Suharsimi Arikunto, Prosedur ..., hal 173

Usman Rianse dan Abdi, Metodologi Penelitian Sosoal dan Ekonomi Teori dan Aplikasi, (Bandung: Alfabeta, 2012), hal 30

Wirdyaningsih, Bank dan Asuransi Islam di Indonesia, (Jakarta: Kencana Prenada Media Group, 2005), hal 41.

Https://id.wikipedia.org/wiki/manajemen_keuangan

Http://nunnapanda.blogspot.co.id/2012/04/bab-1-tujuan-dan-fungsi-manajemen.html 